\title{
ÚJ KUTATÁSI EREDMÉNYEK AKTÍV-ÉBER HIPNÓZISBAN: \\ FENOMENOLÓGIAI, FIZIOLÓGIAI ÉS ENDOKRIN ELEMZÉSEK
}

\author{
KASOS ENIKÖ ${ }^{1,2}$ - KASOS KRISZTIÁN ${ }^{1,2}-$ JÓZSA EMESE$^{2}-$ \\ KÖLTỐ ANDRÁS $S^{2,3}$ - BÁNYAI ÉVA ${ }^{2}$ - VARGA KATALIN ${ }^{2}$ \\ ${ }^{1}$ ELTE Eötvös Loránd Tudományegyetem Pszichológiai Doktori Iskola \\ ${ }^{2}$ ELTE Eötvös Loránd Tudományegyetem Pszichológiai Intézet \\ ${ }^{3}$ National University of Ireland Galway, Health Promotion Research Centre \\ E-mail: kasos.eniko@ppk.elte.hu
}

Beérkezett: 2018. szeptember 6. - Elfogadva: 2019. január 11.

\begin{abstract}
Az aktív-éber hipnózis fontos mérföldkô a hipnózis jelenségének megismerésében: megdöntötte a sokáig uralkodó elméletet, mely szerint a hipnózis az alváshoz hasonló állapot. Mégis viszonylag kevés kutatás foglalkozik a hipnózis aktív formáival, különösen az aktív-éber hipnózis kísérleti vizsgálatával. Tanulmányunk két olyan kutatást foglal össze, amelyben az aktív-éber hipnózis endokrinológiai, elektrodermális és fenomenológiai vonatkozását vizsgáltuk, mindezt az interakciós keret hangsúlyozásával. Az elsố vizsgálatban - elektrodermális aktivitásváltozások elemzése révén - kimutattuk, hogy míg aktív-éber hipnózisban részt vevố, alacsony hipnábilitású alanyoknál az indukció végén is megmarad a mindennapi éber tudatállapotra jellemzố bal féltekei dominancia, addig magas hipnábilitású alanyoknál jobb féltekei túlsúly alakult ki. Ez a mintázat a tudatállapot megfelelô irányú szubjektív módosulásaival is összefügg. A második vizsgálat eredménye, hogy aktív-éber hipnózis mind az alanyok, mind a hipnotizörök kortizol-és oxitocinszintjét befolyásolhatja, és az endokrin változások erôssége összefügg az alany hipnábilitásával, valamint a módosult tudatállapot fenomenológiájával. Ezek az eredmények beilleszthetók a hipnózis interakciós szemléleti keretébe, és alátámasztják az aktív-éber hipnózis jótékony terápiás hatásait.
\end{abstract}

Kulcsszavak: aktív-éber hipnózis, módosult tudatállapot, pszichoendokrinológia, elektrodermális aktivitás, oxitocin, kortizol 


\section{BEVEZETÉS}

Az aktív-éber hipnózis (AÉH) Magyarországon különösen, de más országokban is kedvelt pszichoterápiás módszer. A természetközeli népek gyakran alkalmazták az aktivitásfokozással elért módosult tudatállapotot (MTÁ) gyógyításra, vallási vagy egyéb rítusok során. Az aktivitáshoz kötött transzállapotok megismerésében áttörést jelentett, amikor 1976-ban Bányai Éva kidolgozta a tradicionális relaxációs hipnózis aktív formáját, az aktív-éber hipnózist (Bányai és Hilgard, 1976; Bányai, 2018).

Az AÉH során az alany kerékpár-ergométeren ülve, nyitott szemmel pedálozik és az indukció során a hipnotizôr a frissességet, élénkséget és éberséget hangsúlyozza a hagyományos, relaxációs hipnózisban szuggerált ellazulás és nyugalom helyett. Ez a megközelítés a kísérleti alany vagy terápiás kliens saját erôforrásait és megküzdési képességét helyezi elôtérbe, így a fizikai aktivitás segítségével még inkább alkalmat ad a hipnotikus interakcióban való aktív részvételre (Bányai, Zseni és Túry, 1993). Egészséges önkéntesekkel végzett kutatások kimutatták, hogy az AÉH a hagyományos hipnózistól eltérô szubjektív jellegzetességei a fokozott éberség, pozitívabb érzelmek és aktívabb részvétel (Bányai, 1987).

A jelen cikk célja, hogy bemutassa két olyan újkeletú kutatás eredményeit, amelynek fókusza az AÉH. Az elsố vizsgálatban az elektrodermális aktivitás (EDA) elemzésével következtetünk az agyi lateralitáseltérésekre. Az EDA az agyi elektromos aktivitásnál jóval könnyebben mérhetô és elemezhetô, mozgási mútermékekre kevésbé érzékeny és olcsóbb perifériás mutató, mint a centrális lehetôségek. Mérése révén AÉH-ban is tesztelhetôvé válik a hipnózis egyik legfontosabb neurofiziológiai kérdése: mi történik a hipnotizált alany agyában hipnózis közben, van-e a hipnózisnak jól megragadható objektív mutatója, amely elkülöníti az éberségtől vagy más MTÁ-tól.

A második kutatásban olyan neuroendokrin mutatókat vizsgálunk, amelyeknek a társas interakciók szabályozásában (pl. szülő-gyermek kapcsolatban) betöltött szerepét egyre több kutatási eredmény igazolja. E kutatás során AÉH-ban ismételtük meg kutatócsoportunk egy korábbi, hagyományos hipnózisban elvégzett vizsgálatát. Mivel a hipnózis alkalmas lehet korai kapcsolati sérülések, elakadások korrekciójára, fontos annak vizsgálata, hogy a szülő-gyermek kapcsolatban és más affiliatív helyzetekben bekövetkezô neuroendokrin változások a hipnózis különbözô formáiban is megjelennek-e.

Mindkét vizsgálatunk további egyedi sajátossága, hogy a „kemény” mutatók mellett szubjektív adatokat is elemzünk, és bemutatjuk ezek összefüggéseit. További fontos sajátosság, hogy a hipnózis szociál-pszichobiológiai megközelítésével összhangban, a világ hipnózis-kutatócsoportjai között elsôként az AÉH-ban részt vevô mindkét interakciós partnert vizsgáljuk. A jelen tanulmányban elsố alkalommal közöljük az új eredményeket magyar nyelven.

Kevés vizsgálat foglalkozik az AÉH-val és igen elenyészô számú tanulmány jelent meg ebben a témában magyarul. Mindkét itt bemutatott kutatás fontos abból a szempontból is, hogy az AÉH hatását szubjektív és neurofiziológiai mutatókkal, tehát az élmények mellett a vegetatív idegrendszer, valamint a neuroendokrin rendszer változásainak elemzésével vizsgálják. 


\section{ELEKTRODERMÁLIS AKTIVITÁS AKTÍV-ÉBER HIPNÓZISBAN}

Az itt bemutatott elsô kutatásunkban a hipnózis szimpatikus idegrendszerre gyakorolt hatását vizsgáltuk. Az AÉH közben az agyféltekei dominanciában bekövetkezô változásokat az elektrodermális aktivitás mérésével elemeztük, kihasználva, hogy a bôrellenállás változása az ipszilaterális (azonos oldali) agyfélteke aktivitásváltozását mutatja (Mangina és Beuzeron-Mangina, 1996). Célunk volt az is, hogy a bőrvezetés és a hipnábilitás közti kapcsolatot AÉH-ban vizsgáljuk (K. Kasos, E. Kasos, Kekecs, Szekely és Varga, 2017).

Nem egyértelmú, hogy a hipnózis közben létrejött jobb oldali dominancia a jobb agyféltekei aktivitás növekedésének (Cikurel és Gruzelier, 1990) vagy a bal oldali gátlásának (Gruzelier, Brow, Perry, Rhonder és Thomas, 1984) tulajdonítható. Hipnózis közben a bal agyfélteke szintén fontos szerepet játszik az indukció, majd a szuggesztiók verbális feldolgozásban (Jasiukaitis, Nouriani és Spiegel, 1996), valamint a fókuszált figyelem fenntartásában (Jasiukaitis, Nouriani, Hugdahl és Spiegel, 1997). Feltehetô, hogy hipnózis alatt a feladat jellegének megfelelô, dinamikusan változó interakció megy végbe a két agyfélteke között (Bob és Siroka, 2016). Ez a folyamat Gruzelier neuropszichológiai elmélete szerint már az indukció alatt megindul (Crawford és Gruzelier, 1992).

A kutatásban egy korábban ritkán használt módszerrel, az EDA kétoldali mérésével térképeztük fel a hipnózis és kontroll feltétel közben kimutatható agyféltekei dominancia változásait.

\section{Minta és módszer}

A kutatásban harminckét fizikailag és mentálisan egészséges felnôtt önkéntes vett részt (átlagéletkor: 29,51ะ9,74 év, nôk aránya: 36,5\%). Az alanyok hipnábilitását a vizsgálatot megelôzốen a Harvard Hipnábilitási Csoportskála (Shor és Orne, 1962) magyar változatával (Költô, Gôsi-Greguss, Varga és Bányai, 2015) mértük. Csak azokat hívtuk meg a jelen kutatásban való részvételre, akik a tizenkét pontos skála szerint alacsony (1-4 pont), illetve magas (8-12 pont) hipnábilitási övezetbe estek.

Tudat Fenomenológiája Kérdőív (Phenomenology of Consciousness Inventory: PCI): a Pekala (1991) által kidolgozott kérdőív a különféle helyzetekben létrejövô MTÁ-k intenzitásának és mintázatának mérését teszi lehetôvé (Pekala, 1991). Az önbeszámoló jellegú tesztet az alany az átélt élmény után tölti ki (magyar változatát l. Józsa és mtsai tanulmányában, a jelen tematikus számban, pp. 27-43.).

OpenEDA: a kutatás során az EDA mérése az OpenEDA nyílt forrású 4 Hertz mintavételi aránnyal rendelkezô biomonitorral történt (Kekecs, Szekely és Varga, 2016). A biomonitort a kísérleti alanyok jobb és bal vállán rögzítettük, Skintact FS-RG1 eldobható Ag/AgCl elektródákkal (Leonhard Lang GmbH, Innsbruck, Ausztria; 1. van Dooren, de Vries és Janssen, 2012). Korábbi kutatásokban a váll elektrodermális mérésekre megfelelố helynek bizonyult, valamint ez az elhelyezés lehetóvé tette az alanyok mérések eloótti és utáni akadálytalan mozgását. Az adatok feldolgozásával kapcsolatos részletek az eredeti cikkben megtalálhatóak (Kasos, Kekecs, Kasos, Szekely és Varga, 2018). 
Az elektróda meghibásodása miatt öt résztvevô adatait nem tudtuk rögzíteni. Két, a csoportos beméréskor magas hipnábilitásúként kategorizált alany az AÉH során alacsony hipnábilitásúnak bizonyult. További egy résztvevô adatait hiányosan kitöltött PCI kérdőív miatt nem tudtuk figyelembe venni. Az elemzésben ezért huszonnégy személy adatai szerepelnek.

A résztvevôk két (hipnózis és zenés) véletlenszerú sorrendbe állított kísérleti feltételben vettek részt, ugyanazon a napon, legalább félórás pihenóvel a kettô között. A résztvevốk mindkét feltétel után kérdôíveket töltöttek ki. A jelen elemzésben a PCI eredményeit dolgoztuk fel. A hipnózisfeltétel során a résztvevôk standard AÉH-ban vettek részt, amely a Waterloo-Stanford Hipnábilitási Csoportskála (Bowers, 1998) C változatának szövegét követte (magyar változat: Gósiné-Greguss, 1999). Nem alkalmaztuk azokat a próbákat, amelyekben a kezek mozgatására, negatív vizuális hallucinációra és a korregresszióra vonatkozó szuggesztiókat kapott az alany. Ezek a próbák egyrészt idôigényesek, másrészt a kezek mozgatása, valamint a szemek kinyitása-becsukása befolyásolhatja az EDA-t (Kekecs, Szekely és Varga, 2016). Az indukció 7,5-9 percig tartott. Ebben az elemzésben csak az indukció során regisztrált EDA-eredményeket dolgoztuk fel.

A két feltétel azonos volt, kivéve, hogy a zenés ülések során az indukció helyett egy tizenkét perc, a deindukció (korábbi megnevezéssel: dehipnózis) helyett pedig egy két perc hosszúságú, különbözô típusú zenékbôl álló összeállítást hallottak a résztvevôk, amelyet már korábbi kutatásokban is alkalmaztunk (Kekecs, Szekely és Varga, 2016).

\section{Eredmények}

Varianciaelemzéssel vizsgáltuk, hogy az eltelt idô, az egyes feltételek (AÉH és zene), illetve a hipnábilitási szint szerint van-e különbség az EDA lateralitásában. Vegyes elrendezésû ANOVÁ-t végeztünk, egyszempontos elrendezést alkalmazva az idô (1., 3., 5. és 7. perc) és a két feltétel (hipnózis és zenés) kapcsolatának vizsgálatára, illetve többszempontos ANOVÁ-t a hipnábilitás (magas és alacsony) és a többi feltétel interakciójának vizsgálatára.

A lateralitási együttható, az egyes feltételek, a hipnábilitás és az idô között szignifikáns interakciót találtunk: $\mathrm{F}(3,24)=3,00, \mathrm{p}=0,036$. A két kísérleti feltétel alatt az alacsony és magas hipnábilitású alanyok lateralitási változásai ellentétes mintázatot mutattak. A hipnózis indukciós szakaszának elsố öt percében az alanyok lateralitási eloszlása kiegyenlített volt, de a hetedik percnél az alacsony hipnábilitású alanyoknál bal oldali, míg a magas hipnábilitásúaknál jobb oldali dominanciát figyeltünk meg. Ezzel szemben a zenés feltétel során az alacsony hipnábilitású alanyok mutattak bal oldali és a magas hipnábilitásúak jobb oldali dominanciát, és nem történt számottevô változás a mérések alatt (1. ábra).

A háromfaktoros vegyes elrendezésú ANOVA elemzése szignifikáns idôi fơhatást mutatott a bal oldali bórvezetési szintre $\mathrm{F}(3,24)=4,525, \mathrm{p}=0,006$. Az EDA leginkább a magas hipnábilitású csoportban emelkedett.

A jobb oldali bôrvezetési szint háromfaktoros vegyes elrendezésû ANOVA elemzése szignifikáns interakciót mutatott a kísérleti feltétel, az eltelt idô és a hipnábilitás kö- 

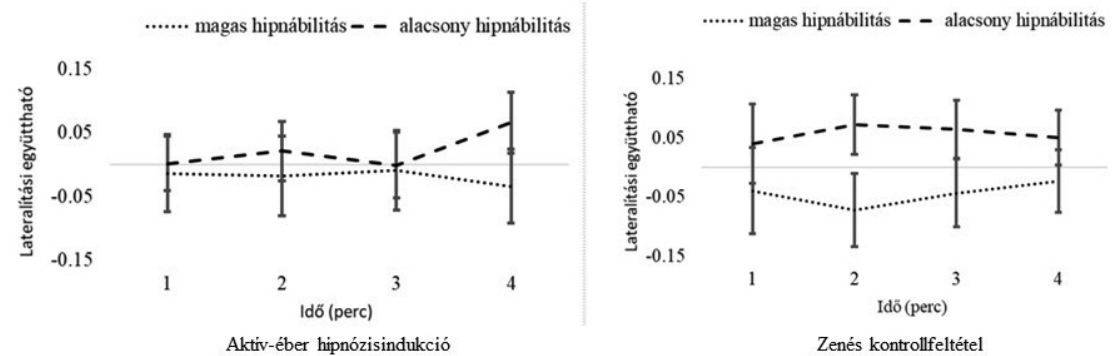

1. ábra. Laterális elektrodermális aktivitás aktív-éber hipnózisindukció és zenés kontrollfeltétel közben. Az alapvonal feletti értékek bal oldali, az alapvonal alatti értékek jobb oldali relatív túlsúlyra utalnak.

zött: $\mathrm{F}(3,24)=3,38, \mathrm{p}=0,023$. A zenés feltételben a magas hipnábilitású alanyok átlagos bőrvezetési szintje magasabb volt, mint az alacsony hipnábilitásúaké, és csökkenô tendenciát mutatott. Az AÉH ezzel ellentétes hatást váltott ki. Az indukció elején az alacsony hipnábilitású alanyok átlagos bôrvezetési szintje volt magasabb, és ez a szint nem változott, míg a magas hipnábilitásúaké az indukció elején alacsonyabb volt, és emelkedó tendenciát mutatott.

A hipnózisban bekövetkezô tudatmódosulás és a lateralitás változása közötti kapcsolat feltérképezéséhez összevetettük a kezdeti és a 7. percben mért lateralitási együttható különbségét a PCI kérdôív dimenzióival) (1. táblázat). Az EDA jobb oldali túlsúly irányába történô változása (a lateralitási együtthatók különbsége negatív) a PCI módosult élmény, testkép, percepció és a tudat módosultságának mértéke dimenzióival pozitívan, míg az öntudat a racionalitás, az akarati kontroll és az emlékezet dimenziókkal negatívan korrelált. Az AÉH feltétellel szemben a zenés feltételben a PCI dimenziói nem mutattak szignifikáns korrelációt a lateralitás változásaival.

1. táblázat. Az aktív-éber hipnózis, illetve a zenés feltétel után felvett PCI kérdôív dimenziói és a lateralitási mutató változása közötti szignifikáns korrelációk

\begin{tabular}{lcc}
\hline \multirow{2}{*}{ PCI-dimenzió } & \multicolumn{2}{c}{ Feltétel } \\
\cline { 2 - 3 } & $\begin{array}{c}\text { Aktív-éber } \\
\text { hipnózisindukció }\end{array}$ & Zene \\
\hline Módosult élmény & $-0,48^{*}$ & 0,10 \\
\hline Testkép & $-0,40^{*}$ & $-0,03$ \\
\hline Percepció & $-0,47^{*}$ & $-0,09$ \\
\hline Öntudat & $0,47^{*}$ & 0,03 \\
\hline A tudat módosultsága & $-0,40^{*}$ & 0,07 \\
\hline Racionalitás & $0,56^{* *}$ & $-0,25$ \\
\hline Akarati kontroll & $0,41^{*}$ & $-0,23$ \\
\hline Emlékezet & $0,62^{* *}$ & 0,22 \\
\hline
\end{tabular}

Megjegyzés: A negatív korreláció az adott PCI-dimenzió és a jobb féltekei túlsúly kapcsolatára, a pozitív korreláció a PCI-dimenzió és a bal féltekei túlsúly kapcsolatára utal. ${ }^{*} \mathrm{p}<0,05,{ }^{* *} \mathrm{p}<0,01$. 


\section{Megbeszélés}

Kutatásunk a bốrvezetés vizsgálatával mérte fel, hogy AÉH alatt milyen változások történnek a lateralitásban, és ezek összefüggenek-e az alanyok szubjektív élményeivel. Eredményeink szerint az alacsony hipnábilitású alanyoknál AÉH alatt is megmarad a bal oldali dominancia, míg a magas hipnábilitásúakra a jobb oldali túlsúly a jellemzó. Ugyanakkor a zenés feltétel közben az alanyok lateralitása nem mutatott változást, tehát az elmozdulás az aktív-éber hipnotikus indukció sajátos hatásának tulajdonítható, amely máshogyan hat alacsony és magas hipnábilitású alanyokra.

A szubjektív élmények hipnózis alatti változásai is azt sugallják, hogy a magasabb jobb oldali EDA együtt jár az agyféltekei dominancia jobbra tolódásával. A PCI hipnózishoz kapcsolható dimenziói (a tudat módosulásának mértéke, a testkép és a percepcióváltozása) szignifikáns korrelációt mutatnak az indukció alatti jobb agyféltekei eltolódással. Ez alátámasztja Gruzelier (1996) megfigyelését, amely szerint a magas hipnábilitású alanyoknál az indukció frontális aktivációt, jobb posterior dominanciát és ezzel együtt bal oldali gátlást vált ki (Gruzelier, 1996). Az alacsony hipnábilitás ezzel ellentétes mintázatot, bal oldali aktivációt mutat (Warren, 1993), amely bal oldali elektrodermális túlsúlyban nyilvánul meg. Ez a mintázat, feltehetôen az indukció verbális feldolgozásának, valamint a fókuszált figyelemnek tulajdonítható (Rainville, Hofbauer, Paus, Duncan, Bushnell és Price, 1999). A magas hipnábilitás magasabb kognitív rugalmassággal járhat együtt, amelyet a hipnózis tovább növel (Crawford, 1989, 2001). Ez az alacsony hipnábilitású alanyokra nem jellemzó hasonló mértékben. Az AÉH közben megfigyelt jobb oldali EDA jobb agyféltekei múködési túlsúly lehet a mechanizmus, amely a mély bevonódást és az erôfeszítés nélküli összpontosítást segíti a magas hipnábilitású alanyoknál.

Az AÉH után kitöltött PCI nyolc dimenziója mutatott szignifikáns korrelációt az elektrodermális lateralitás változásával. E dimenziók közül hét a hipnotikus fogékonysággal is szignifikánsan korrelált. Minél erôteljesebb volt a jobb oldali elektrodermális eltolódás, annál nagyobb pontszámot ért el a személy a módosult élmény, a tudat módosulásának mértéke, percepció és a testkép dimenziókon. A bal oldali bőrvezetés túlsúlya a racionalitás, öntudat, akarati kontroll és a memória dimenziók magasabb értékével járt együtt. Fontos megemlíteni, hogy míg az elektrodermális megfigyelések az indukció elsố hét percére vonatkoztak, a PCI-t a résztvevook az ülés (hipnózis vagy zenés feltétel) egészére vonatkozóan töltötték ki, tehát már a folyamat elsố perceinek objektív mutatói szoros kapcsolatban állnak az egész interakcióra vonatkozó szubjektív beszámolókkal.

Az indukció meghatározó szerepére utal az is, hogy a zenés feltételben nem találtunk az AÉH-hoz hasonló korrelációkat a szubjektív élmények és a lateralitási eltolódás között. Ugyanakkor az alanyok mindkét feltétel alatt hasonlóan reagáltak a szuggesztiókra, bár a zenehallgatás után valamennyivel kevésbé. Korábbi kutatásokban (pl. McGeown és mtsai, 2012) is megfigyelték, hogy magas hipnábilitású alanyok az indukció hiányában is engedelmeskedtek az elhangzott szuggesztióknak, de az indukció hatására erósebb agyi aktivitást lehetett kimutatni. Azaz lehet, hogy viselkedéses szinten nincs különbség a hipnotikus indukció nélkül vagy indukció után a szuggesztiók végrehajtásában, de neurofizológilag mégis kimutatható az eltérés. Ez kifejezetten megkülönbözteti a hipnózist a zenés kontrollfeltételtôl. 
A kutatás megerôsítette, hogy a hipnózis alatt lateralitásváltozás mutatható ki, valamint tudomásunk szerint elsóként vizsgálta a szubjektív élmény és az elektrodermális lateralitás közötti korrelációt. Úgy tûnik, az EDA változásának követése lehetôvé teszi a hipnotikus bevonódás és a tudat módosulásának valós idôben történô megfigyelését anélkül, hogy az alanytól rövid idôközönként ismételve verbális beszámolót kérnénk. Így az EDA mérése további interakciós kutatások fontos eszköze lehet.

\section{HORMONÁLIS VÁLTOZÁSOK AKTÍV-ÉBER HIPNÓZISBAN}

Egyre több olyan interakciós megközelítésû vizsgálatot végeznek, amelyek során az alanyban és a hipnotizórben lezajló változásokat egyaránt vizsgálják. Az itt bemutatott második kutatás a centrális oxitocin (OT) mint a társas affiliációt szabályozó neurotranszmitter és a kortizol mint stresszhormon változását vizsgálta AÉH-ban (E. Kasos, Kasos, Pusztai, Polyák, Kovács és Varga, 2018).

A centrális OT szerepe igazolt a társas affiliációban és a kötôdésben (Olff és mtsai, 2013). Pozitív hatással van a társas kognícióra, a memóriára, a felismerésre és motivációra, ugyanakkor felerôsítheti a negatív elôítéleteket is (De Dreu, 2012). Hipnózis közben az OT megnöveli az alanyok szuggesztibilitását (Bryant, Hung, Guastella és Mitchell, 2012), de negatív hatással van az emlékezetre (Parris, Dienes, Bate és Gothard, 2014). Úgy tûnik, a hipnotikus szuggesztiók közvetlenül nem befolyásolják a kortizolszint változását, de az általuk elôhívott érzelmek igen (Adlercreutz, Kuoppasalmi, Närvänen, Kosunen és Heikkinen, 1982).

Varga és Kekecs (2014) - hagyományos relaxációs hipnózist alkalmazva - férfi résztvevôk OT- és kortizolszintjének változását vizsgálták, és szignifikáns csökkenést mutattak ki mind az alany, mind a hipnotizôr kortizolszintjében. A hipnábilitás és a hormonális változások között nem találtak szignifikáns korrelációt, ugyanakkor a Diádikus Interakciós Harmónia kérdôív (DIH) összhang alskálája szignifikáns korrelációt mutatott az alany oxitocinszintjének emelkedésével. Amikor az alany kevésbé meleg gyerekkori szülôi kapcsolatokról számolt be, a hipnotizôr oxitocinszintje jobban megemelkedett.

Az itt bemutatott kutatásban a Varga és Kekecs (2014) által alkalmazott módszerrel végeztük el AÉH ülések résztvevôinek vizsgálatát. Feltételeztük, hogy az általuk megfigyelt hormonális változások aktivitásfokozással elért hipnózisban is kimutathatók.

\section{Minta és módszer}

A kutatásban 31 nô (átlagéletkor: 23,28ะ3,54 év) és öt nôi hipnoterapeuta (átlagélet-

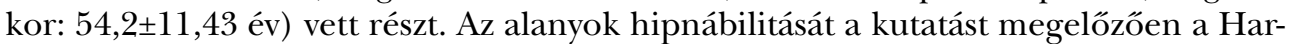
vard Hipnábilitási Csoportskála (Shor és Orne, 1962) magyar változatával (Költô és mtsai, 2015) mértük be. Minden hipnotizốr két alacsony (1-6) és két magas (7-12 pontos) hipnábilitású alannyal dolgozott. A kutatásban azok az önbevallásuk alapján egészséges nôk vehettek részt, akik nem szedtek hormon tartalmú készítményeket, például fogamzásgátlót. Feldman és munkatársai (Feldman, Gordon, Schneiderman, 
Weisman és Zagoory-Sharon, 2010) nem találtak összefüggést az anyai OT és a menstruációs ciklus fázisai között, ezért, és a beosztási nehézségek miatt, a résztvevoók menstruációs ciklusát nem vettük figyelembe a kutatás során.

Tudat Fenomenológiája Kérdôív (Phenomenology of Consciousness Inventory: PCI): lásd mint fent.

Archaikus Bevonódási Skála (ABS): a Nash és Spinler (1989) által kidolgozott tizenkilenc tételes skála kutatócsoportunk által kibôvített és a hipnotikus interakció mindkét résztvevôjére adaptált változatát (l. Bányai, Józsa és Költố tanulmányát a jelent tematikus számban, pp. 45-61.) alkalmaztuk a résztvevôk áttételi érzelmeinek mérésére. A jelen tanulmányban csak a tizenkilenc pozitív tétellel kapott eredményeket elemezzük.

A Diádikus Interakciós Harmónia (DIH) kérdôívet munkacsoportunk interakciós kutatásai során kétszemélyes interakciós helyzetek vizsgálatára fejlesztette ki. A kérdôív kiválóan alkalmas az azonos interakcióban részt vevô vizsgálati személyek interakcióra vonatkozó élményeinek összehasonítására (Varga, Józsa, Bányai és Gôsi-Greguss, 2006). Az eredeti kérdốiv ötven tételbôl áll, ahol a vizsgálati személyek egy ötfokú Likert-skálán jelzik, hogy az egyes jelzôk mennyire írják le átélt élményeiket. A jelen kutatásban a kérdő́iv rövidített változatát használtuk, amelynek alskálái 1. intimitás, 2. összhang, 3. játékosság és 4. feszültség. Mind az alanyok, mind a hipnotizôrôk kérdōive jó megbízhatósági mutatókkal rendelkezik, a Cronbach-alfa értékek 0,72 és 0,92 közöttiek.

Az Emlékeim a Szülői Nevelésról kérdőív (Egna Minnen Beträffande Uppfostran, rövidített változat, EMBU): a felnôttek saját neveltetésükkel kapcsolatos emlékeit vizsgálja (Arrindell és mtsai, 1999). Az általunk használt 23 tételes változatban, a vizsgálati személyek külön értékelték anyjuk és apjuk nevelési stílusát. A kérdôívnek három alskálája van: 1. visszautasitás, 2. érzelmi melegség és 3. túlvédés (az EMBU részletes bemutatását 1. Költô, Józsa és Bányai tanulmányában a jelen tematikus számban, pp. 63-78.).

Annak érdekében, hogy a cirkadián ritmus hormonháztartásra gyakorolt hatását egységesítsük, minden hipnózis 11 és 13 óra között történt. Megkértük a résztvevôket, hogy a hipnózis elôtt tartózkodjanak a koffein-, illetve alkoholtartalmú készítményektôl, ne dohányozzanak, illetve a hipnózist megelôzố egy órában már csak vizet vegyenek magukhoz. A résztvevôk külön érkeztek és külön helyiségben várakoztak legalább 15 percig, hogy az érkezés okozta stressz csökkenjen. Ezalatt kitöltötték a beleegyezô nyilatkozatot, majd 15 perc elteltével levettük az elsố nyálmintát.

A mintavétel után az alanyt bevezettük a hipnózisoknak helyet adó hangszigetelt kísérleti kamrába, ahol beállítottuk a kerékpár-ergométert, majd a hipnotizőr is bejött és bemutatkozott az alanynak. A hipnózis a Stanford Hipnotikus Szuszceptibilitási Skála C változatának (Weitzenhoffer és Hilgard, 1962) szövegét követte, melyet Bányai és Hilgard (1976) alakított át az aktív-éber hipnózisra. A hipnózis után a résztvevôk külön helyiségbe tértek vissza, és meghatározott sorrendben kitöltötték a kérdôíveket (ABS, PCI, DIH, valamint a Spielberger Állapot- és Vonásszorongás Kérdôív). Tizenöt perc elteltével a második nyálmintát is levettük. Az alanyok ezt követôen töltötték ki az EMBU kérdôívet, ezzel biztosítva, hogy a nyálminta levétele elôtt a szülői kapcsolatokra semmilyen utalás ne történjen. 
A harmincegy hipnózis során két alkalommal levett nyálminta közül hetvenkét minta mennyisége érte el a kívánt szintet az OT, és hatvanhét mintáé a kortizolszint elemzéséhez.

\section{Eredmények}

Az összetartozó mintás t-próba szerint a hipnotizôr kortizolszintje a hipnózis során szignifikánsan csökkent: $t(14)=2,33, p=0,035$, Cohen- $d=0,60$, míg az alany kortizolszintjében nem találtunk szignifikáns változást. A résztvevook kortizolszintje és a hipnábilitás között nem volt szignifikáns összefüggés. Ellenben az alany hipnábilitása és az OT alapszintje (Spearman- $r=0,58, p=0,011$ ), valamint a hipnábilitás és az OT-szint változása között (Spearman- $r=0,70, p=0,001$ ) szignifikáns összefüggést mértünk.

Többszempontos varianciaanalízist végeztünk a hipnábilitás mértéke és az OT-szint vizsgálatára. Itt az összetartozó szempont a hipnózis elōtt és után mért OT-szint, míg a független szempont az alacsony (1-6) és magas (7-12) hipnábilitás. Szignifikáns interakciót találtunk az OT-szint és a hipnábilitás között: $F(1,17)=8,63, p=0,01, \eta^{2}$ p = 0,35, de nem volt szignifikáns fớhatás. Az alacsony hipnábilitású alanyok OT-szintje magasabb, míg a magas hipnábilitásúaké alacsonyabb volt a hipnózis után, mint az alapvonalon.

Az OT-szint lehetséges változása szerint három csoportot tudtunk elkülöníteni. Az elsố csoport OT-szintje emelkedett, a másodiké nem változott, míg a harmadiké csökkent. Egyszempontos varianciaanalízis alkalmazásával a három csoport között hipnábilitás szerinti különbséget találtunk: $F(2,15)=5,25 p=0,019 \eta_{\mathrm{p}}^{2}=0,41$. A Bonferroni-korrekciót követően végzett független mintás t-próba szerint szignifikáns különbség volt a növekvô és a nem változó OT-szintû csoport hipnábilitása között: $t(11)=$ 2,62, $p=0,044$, illetve a növekvô és a csökkenô OT-szintes csoport között: $t(6)=4,45$, $p=0,020$. Az emelkedó OT-szintú csoport átlagos hipnábilitása szignifikánsan alacsonyabb volt, mint a másik két csoporté.

A szubjektív élmények vizsgálata során az alanyok által kitöltött s-EMBU kérdôív apai túlvédés alskálája szignifikáns negatív korrelációt mutatott a hipnotizôr OT-változásával: $r=-0,48, p=0,045$.

A PCI-pontszámok szerint az alanyok, akiknek magasabb volt OT-szintje a hipnózis végén, kevésbé éltek át tudatállapot-módosulást, annál erôsebb maradt az öntudatuk, kevésbé torzult az idôérzékük és a percepciójuk, és alacsonyabb koncentrációt és vizuális képzeleti élénkséget jelentettek. A hipnózis utáni magas kortizol ugyanakkor több és élénkebb vizuális képzelettel járt együtt. Amikor a hipnotizőr kortizolszintje jobban emelkedett a hipnózis során, az alany erósebbnek ítélte a saját racionalitását a hipnózis alatt. Viszont az alanyok OT-szint emelkedése esetén a hipnotizôr alacsonyabbnak értékelte a saját tudatállapot módosulásának mértékét és az arousaljét.

Az adatok részletesebb és teljesebb körû elemzése megtalálható az eredeti cikkekben. 


\section{Megbeszélés}

Hagyományos hipnózisban szignifikáns csökkenés mutatható ki mind az alany, mind a hipnotizôr kortizolszintjében, ami a relaxációra, nyugalomra vonatkozó szuggesztiókkal magyarázható (Varga és Kekecs, 2014). A jelen vizsgálatban azt figyeltük meg, hogy AÉH közben az alanyok kortizolszintje nem mutatott szignifikáns változást, míg a hipnotizóré csökkent. Ez a különbség valószínúleg annak tudható be, hogy míg a hipnotizőr a hagyományos helyzethez hasonló nyugalmi (bár nem ülô, hanem álló) helyzetben van, addig az alany a kerékpár-ergométeren ülve, ellenállásnak kitéve pedálozik. Korábbi kutatásokban mozgás hatására az alanyok kortizolszintje emelkedett (Kirschbaum és Hellhammer, 1994), de úgy tûnik, hogy a mozgás hatását a mi vizsgálatunkban a hipnózis „kiegyensúlyozta”, ami az AÉH és a hagyományos hipnózis hasonlóságára mutat rá.

A magas hipnábilitású alanyok OT-szintje csökkent a hipnózis alatt, az alacsony hipnábilitásúaké növekedett, míg a közepeseké nem változott. Hipnoterápiával foglalkozó szakemberek szerint a kliensek (viselkedéses skálákkal mért) hipnábilitása nem befolyásolja, hogy mennyire eredményes a terápia, ha a kliens motivált a változásra és hajlandó együttmúködni (Barabasz, Olness, Boland és Kahn, 2010). Kutatásunk eredményei is alátámasztják, hogy azok az alanyok is megtapasztalhatják a hipnózis jótékony hatását, akik nem mutatnak megfigyelhetô viselkedéses reakciókat.

Hasonló mintázat figyelhetô meg a fenomenológiai mutatók vizsgálatánál. Azok az alanyok, akiknél a hipnózis után az OT-szint magasabb volt, csökkent a tudat módosulásának mértéke, míg az öntudat szintje magasabb értéket mutatott, kevésbé torzult az idôérzék és a percepció, valamint alacsonyabb volt a koncentráció és a vizuális képzelet élénksége. Ezek az eredmények szintén azt látszanak alátámasztani, hogy a hipnózis interakciós hatására azoknál az alanyoknál is aktiválódik az OT-rendszer, akik amúgy (a viselkedés vagy az élmények szintjén) kevésbé vonódnak be a hipnózisba. Ez az eredmény azért fontos, mert igazolni látszik, hogy a hipnózis hormonális szinten is jótékony hatású lehet az alacsony hipnábilitású alanyokra is.

Az alanyok esetében a nagyobb kortizolszint-emelkedés a PCI vizuális képzelet (menynyisége és élénksége) dimenzióján elért magasabb pontszámmal járt együtt. Mintha a vizuális képzelet egyfajta belsô munkát, erófeszítést jelentene, amely stresszorként jelentkezik. A mentális imagináció a hipnózis egyik központi eleme (Landry, Lifshitz és Raz, 2017), és azok, akik élénkebb vizualizációra képesek, jobban érzékelik a hipnózis pozitív hatásait (Kwekkeboom, Huseby-Moore és Ward, 1998; Watanabe, Fukuda, Hara, Maeda, Ohira és Shirakawa 2006). Ennek a belsố munkának a segítése, fejlesztése elôsegítheti az alanyok hipnózisba történô bevonódását. Ezért fontos, hogy a hipnoterápiára való szocializáció során a terapeuta kezdetben énerôsítô, pozitív szuggesztiókat és képzeleti képeket alkalmazzon.

Amikor a hipnózisban az alany és a hipnotizôr adatait együtt vizsgáltuk, számos statisztikai összefüggést találtunk, amely a két résztvevô élményeinek és pszichoendokrin változásainak kölcsönösségére utalt. A hipnotizôr hipnózis utáni kortizolszintje pozitív korrelációt mutatott az alany PCI racionalitás aldimenzióján jelzett pontszámával, míg az alany magasabb OT-szintje a hipnotizôr által kevésbé intenziven átélt arousallel és tudatmódosulással járt együtt. Mintha a diád tagjai kompenzálnák a másik elmozdulá- 
sát, ami összhangban van az affiliációs konfliktus elmélettel (Argyle és Dean, 1965) és kutatócsoportunk alany-hipnotizôr diádok élményeit vizsgáló klaszteranalitikus kutatásának eredményeivel (Józsa, 2012) is. Az elmélet szerint egy interakció résztvevôi az intimitás kényelmes szintjére törekszenek, amelyet a megközelítés és elkerülés egyensúlyba hozásával igyekeznek elérni. Mind az eredmények, mind az elmélet alátámasztani látszik, hogy a résztvevốk együtt - és egymásra hatást gyakorolva - alakítják a hipnózishelyzetet. Mindez illeszkedik a hipnózis szociál-pszichobiológiai elméletébe (Bányai, 1991, valamint l. Bányai tanulmányát a jelen tematikus számban, pp. 7-26.).

A hipnotizốr hipnózis alatti kortizolszint-változása pozitív korrelációt mutatott az alany PCI racionalitás dimenzióján elért pontszámmal. Mintha a hipnotizőr stresszként élte volna meg, hogy az alany nem vonódott be a hipnózis élményébe, vagy fordítva, a hipnotizőr magasabb stresszszintje megakadályozhatta, hogy az alany el tudja magát engedni. Hasonlóan, Sachar, Cobb és Shor (1966) azt találták, hogy az alanyok pozitív archaikus bevonódása együtt járt (saját) kortizolszintjük csökkenésével, míg a konfliktusos bevonódás nem.

A hagyományos hipnózisban végzett vizsgálat eredménye alapján (Varga és Kekecs, 2014) negatív korrelációt vártunk az alany által felidézett szülôi érzelmi melegség és a hipnotizőr OT változása között. Ehelyett AÉH közben az alany által felidézett apai túlvédés alskála és a hipnotizőr OT változása között találtunk szignifikáns összefüggést. E különbség egyik lehetséges oka lehet az, hogy míg a tradicionális hipnózis során férfi alanyokat és hipnotizôröket vizsgáltak, addig AÉH-ban csak nôk vettek részt. Ez befolyással lehetett a hipnózis stílusára és a résztvevốk közötti dinamikára is (Varga, 2013; Varga, Bányai és Gôsi-Greguss, 2004).

Eredményünk megerôsíti azt az elképzelést, hogy az alany a hipnózishelyzetbe „magával hozza” a szülókkel kapcsolatos implicit kötődési mintáit, és a hipnotizôr élményei rezonálnak erre. Számos kutatás fókusza volt az OT-szint változása a szülố-gyermek interakció során. Feldman, Gordon, Schneiderman, Weisman és Zagoory-Sharon (2010) a szülôi szerep megélésének fontosságára figyelt fel. Az anyák magasabb OT-szint emelkedését mutatták ki szeretetteljes, gondoskodó viselkedés közben, míg az apáknál a gyermekkel való stimuláló játék közben tapasztalták ezt. Ez érthetóbbé teszi, miért volt más az EMBU-faktorok és az OT-változások kapcsolata férfi és nôi hipnotizőrök esetében. Azok a kutatások, amelyek korrelációt találtak szülók és gyermekeik OT-szintje között, az öröklődés és OT-rendszer kapcsolatát látszanak igazolni (Feldman és mtsai, 2010). Ugyanakkor az emberi OT-rendszer érzékeny a korai életeseményekre is (Feldman és mtsai, 2010). Ezt a II. világháborúban szüleiktốl elválasztott gyermekek vizsgálata is igazolta: míg csak az apától való elválasztás nem okozott szignifikáns változást, addig mindkét szülő elvesztése jelentôs hatással volt a kortizolszint változására és a felnôttkori depresszió mértékére (Pesonen, Raikkonen, Heinonen, Kajantie, Forsen és Eriksson, 2007).

Vizsgálatunk eredményei a társas affiliációk szabályozó hatását is alátámasztják. Az interperszonális interakciók során a védekezés és a kötődés közötti egyensúly kialakítása nélkülözhetetlen. A fenyegetés és bizonytalanság leküzdése és a védekezô mechanizmusok gyengülése után elôtérbe kerül a bizalom és gondoskodás, a kötôdés és a közelség megtapasztalására való képesség (De Dreu, 2012; Taylor, Gonzaga, Klein, Hu, P., Greendale és Seeman, 2006). Ezek az eredmények a hipnózis szociál-pszicho- 
biológia elméletével egybehangzóan hangsúlyozzák a korrektív tapasztalatok és ezen belül is a hipnoterápia szerepét, fontosságát (Bányai, 1991).

A hipnotikus interakció során a résztvevôk hormonális változásainak mérése nemcsak a hipnózis jobb megértése szempontjából fontos. Ha jobban feltárjuk a résztvevôk OT- és kortizolszintjének (kölcsönös) szabályozását, ebból indirekt módon következtethetünk arra is, hogy a hipnózissal vagy más MTÁ-val végzett pszichoterápiában hogyan történik a negatív élmények korrekciója, a védekezó és megküzdési mechanizmusok támogatása, a kliens énjének megerôsítése és erőforrásainak mozgósítása.

\section{IRODALOM}

Adlercreutz, H., Kuoppasalmi, K., Närvänen, S., Kosunen, K., \& Heikkinen, R. (1982). Use of hypnosis in studies of the effect of stress on cardiovascular function and hormones. Acta Medica Scandinavica, 211(660 S), 84-94.

Argyle, M., \& Dean, J. (1965). Eye-contact, distance and affiliation. Sociometry, 28(3), 289-304.

Arrindell, W. A., Sanavio, E., Aguilar, G., Sica, C., Hatzichristou, C., Eisemann, M., ... Van Der Ende, J. (1999). The development of a short form of the EMBU: Its appraisal with students in Greece, Guatemala, Hungary and Italy. Personality and Individual Differences, 27(4), 613-628.

Bányai É. (1987). Aktivitás-fokozással létrehozható módosult tudatállapot: Aktív-éber hipnózis. Budapest: Eötvös Loránd Tudományegyetem.

Bányai, É. (1991). Toward a social-psychobiological model of hypnosis. In J. W. Rhue \& S. J. Lynn (Eds), Theories of hypnosis: Current models and perspectives (pp. 564-598). New York, NY, US: Guilford Press.

Bányai, É. (2018). Active-alert hypnosis: History, research, and applications. American Journal of Clinical Hypnosis, 61(2), 88-107.

Bányai, É., \& Hilgard, E. R. (1976). A comparison of active-alert hypnotic induction with traditional relaxation induction. Journal of Abnormal Psychology, 85(2), 218-224.

Bányai, É., Zseni, A., \& Túry, F. (1993). Active-alert hypnosis in psychotherapy. In J. W. Rhue, S. J. Lynn, \& I. Kirsch (Eds), Handbook of clinical hypnosis (pp. 271-290). Washington, DC, US: American Psychological Association.

Barabasz, A. F., Olness, K., Boland, R., \& Kahn, S. (2010). Medical Hypnosis Primer: Clinical and Research Evidence (xviii, 133). Brunner-Routledge.

Bob, P., \& Siroka, I. (2016). Attentional dissociation in hypnosis and neural connectivity: preliminary evidence from bilateral electrodermal activity. International Journal of Clinical and Experimental Hypnosis, 64(3), 331-349.

Bowers, K. S. (1998). Waterloo-Stanford Group Scale of Hypnotic Susceptibility, Form C: Manual and response booklet. International Journal of Clinical and Experimental Hypnosis. United Kingdom: Taylor \& Francis.

Bryant, R. A., Hung, L., Guastella, A. J., \& Mitchell, P. B. (2012). Oxytocin as a moderator of hypnotizability. Psychoneuroendocrinology, 37(1), 162-166.

Cikurel, K., \& Gruzelier, J. (1990). The effect of an active-alert hypnotic induction on lateral asymmetry in haptic processing. British Journal of Experimental and Clinical Hypnosis, 7(1), $17-25$.

Crawford, H. J. (1989). Cognitive and physiological flexibility: Multiple pathways to hypnotic responsiveness. In V. A. Gheorghiu, P. Netter, H. J, Eysenck, \& R. Rosenthal (Eds), Suggestion and Suggestibility: Theory and Research (pp. 155-168). Berlin: Springer Verlag. 
Crawford, H. J. (2001). Neuropsychophysiology of hypnosis: Towards an understanding of how hypnotic interventions work. In G. D. Burrows, R. O. Stanley, \& P. B. Bloom (Eds), International handbook of clinical hypnosis (pp. 61-84). Chichester, New York: Wiley: John Wiley \& Sons, Ltd.

Crawford, H. J., \& Gruzelier, J. H. (1992). A midstream view of the neuropsychophysiology of hypnosis: Recent research and future directions. In E. Fromm \& M. R. Nash (Eds), Contemporary Hypnosis Research (pp. 227-266). New York, NY, US: Guilford Press.

De Dreu, C. K. W. (2012). Oxytocin modulates cooperation within and competition between groups: An integrative review and research agenda. Hormones and Behavior, 61(3), 419-428.

Feldman, R., Gordon, I., Schneiderman, I., Weisman, O., \& Zagoory-Sharon, O. (2010). Natural variations in maternal and paternal care are associated with systematic changes in oxytocin following parent-infant contact. Psychoneuroendocrinology, 35(8), 1133-1141.

Feldman, R., Gordon, I., \& Zagoory-Sharon, O. (2010). The cross-generation transmission of oxytocin in humans. Hormones and Behavior, 58(4), 669-676.

Gruzelier, J. (1996). The state of hypnosis : Evidence and applications. OJM: An International Journal of Medicine, 89(4)(June), 313-317.

Gruzelier, J., Brow, T., Perry, A., Rhonder, J., \& Thomas, M. (1984). Hypnotic susceptibility: A lateral predisposition and altered cerebral asymmetry under hypnosis. International Journal of Psychophysiology, 2(2), 131-139.

Gôsiné Greguss, A. (1999). Waterloo-Stanford Hipnábilitási Csoportskála C forma (WSGC). Kézirat. Budapest: Eötvös Loránd Tudományegyetem Bölcsészettudományi Kar

Jasiukaitis, P., Nouriani, B., Hugdahl, K., \& Spiegel, D. (1997). Relateralizing hypnosis: Or, have we been barking up the wrong hemisphere? International Journal of Clinical and Experimental Hypnosis, 45(2), 158-177.

Jasiukaitis, P., Nouriani, B., \& Spiegel, D. (1996). Left hemisphere superiority for event-related potential effects of hypnotic obstruction. Neuropsychologia, 34(7), 661-668.

Józsa E. (2012). Diádikus interakciós élménymintázatok. Doktori (PhD) disszertáció. Budapest: Eötvös Loránd Tudományegyetem Pszichológiai Doktori Iskola.

Kasos, E., Kasos, K., Pusztai, F., Polyák, Á., Kovács, K. J., \& Varga, K. (2018). Changes in oxytocin and cortisol in active-alert hypnosis: Hormonal changes benefiting low hypnotizables. International Journal of Clinical and Experimental Hypnosis, 66(4), 404-427.

Kasos, K., Kasos, E., Kekecs, Z., Szekely, A., \& Varga, K. (2017). Bilateral electrodermal activity in active-alert hypnosis. Poster at the XIV. European Society of Hypnosis Conference (1). Manchester.

Kasos, K., Kekecs, Z., Kasos, E., Szekely, A., \& Varga, K. (2018). Bilateral electrodermal activity in the active-alert hypnotic induction. International Journal of Clinical and Experimental Hypnosis, 66(3), 282-297.

Kekecs, Z., Szekely, A., \& Varga, K. (2016). Alterations in electrodermal activity and cardiac parasympathetic tone during hypnosis. Psychophysiology, 53(2), 268-277.

Kirschbaum, C., \& Hellhammer, D. H. (1994). Salivary cortisol in psychoneuroendocrine research: Recent developments and applications. Psychoneuroendocrinology, 19(4), 313-333. Pergamon.

Költô, A., Gôsi-Greguss, A. C., Varga, K., \& Bányai, É. I. (2015). Hungarian Norms for the Harvard Group Scale of Hypnotic Susceptibility, Form A. International Journal of 19(4), 313-333. Clinical and Experimental Hypnosis, 63(3), 309-334.

Kwekkeboom, K., Huseby-Moore, K., \& Ward, S. (1998). Imaging ability and effective use of guided imagery. Research in Nursing and Health, 21(3), 189-198.

Landry, M., Lifshitz, M., \& Raz, A. (2017). Brain correlates of hypnosis: A systematic review and meta-analytic exploration. Neuroscience and Biobehavioral Reviews 81(Pt A), 75-98. 
Mangina, C. A., \& Beuzeron-Mangina, J. H. (1996). Direct electrical stimulation of specific human brain structures and bilateral electrodermal activity. International Journal of Psychophysiology, 22(1-2), 1-8.

McGeown, W. J., Venneri, A., Kirsch, I., Nocetti, L., Roberts, K., Foan, L., \& Mazzoni, G. (2012). Suggested visual hallucination without hypnosis enhances activity in visual areas of the brain. Consciousness and Cognition, 21(1), 100-116.

Nash, M., \& Spinler, D. (1989). Hypnosis and transference: A measure of archaic involvement. International Journal of Clinical and Experimental Hypnosis, 37(2), 129-144.

Olff, M., Frijling, J. L., Kubzansky, L. D., Bradley, B., Ellenbogen, M. A., Cardoso, C., Bartz, J. A., van Zuiden, M. (2013). The role of oxytocin in social bonding, stress regulation and mental health: An update on the moderating effects of context and interindividual differences. Psychoneuroendocrinology, 38(9), 1883-1894.

Parris, B. A., Dienes, Z., Bate, S., \& Gothard, S. (2014). Oxytocin impedes the effect of the word blindness post-hypnotic suggestion on Stroop task performance. Social Cognitive and Affective Neuroscience, 9(7), 895-899.

Pekala, R. J. (1991). Quantifying Consciousness: An Empirical Approach. New York, USA: Plenum Press.

Pesonen, A.-K., Räikkönen, K., Heinonen, K., Kajantie, E., Forsén, T., \& Eriksson, J. G. (2007). Depressive symptoms in adults separated from their parents as children: A natural experiment during World War II. American Journal of Epidemiology, 166(10), 1126-1133.

Rainville, P., Hofbauer, R. K., Paus, T., Duncan, G. H., Bushnell, M. C., \& Price, D. D. (1999). Cerebral mechanisms of hypnotic induction and suggestion. Journal of Cognitive Neuroscience, 11(1), 110-125.

Sachar, E. J., Cobb, J. C., \& Shor, R. E. (1966). Plasma cortisol changes during hypnotic trance: Relation to depth of hypnosis. Archives of General Psychiatry, 14(5), 482-490.

Shor, R. E., \& Orne, E. C. (1962). Harvard Group Scale of Hypnotic Susceptibility, Form A. Palo Alto, USA: Consulting Psychologists Press.

Taylor, S. E., Gonzaga, G. C., Klein, L. C., Hu, P., Greendale, G. A., \& Seeman, T. E. (2006). Relation of oxytocin to psychological stress responses and hypothalamic-pituitary-adrenocortical axis activity in older women. Psychosomatic Medicine, 68(2), 238-245.

van Dooren, M., de Vries, J. J. G. G. J., \& Janssen, J. H. (2012). Emotional sweating across the body: Comparing 16 different skin conductance measurement locations. Physiology and Behavior, 106(2), 298-304.

Varga, K. (2013). The phenomenology of hypnotic interactions. Hauppauge, NY, US: Nova Science Publishers.

Varga, K., Bányai, É. I., \& Gôsi-Greguss, A. C. (2004). A hipnotizôr a hipnotikus interakcióban: a szubjektív élmények elemzése. Pszichoterápia, 13(3), 140-147.

Varga, K., Józsa, E., Bányai, É. I., \& Gốsi-Greguss, A. C. (2006). A new way of characterizing hypnotic interactions: Dyadic Interactional Harmony (DIH) questionnaire. Contemporary Hypnosis, 23(4), 151-166.

Varga, K., \& Kekecs, Z. (2014). Oxytocin and cortisol in the hypnotic interaction. The International Journal of Clinical and Experimental Hypnosis, 62(1), 111-28.

Warren, K. (1993). Neuropsychological evidence of reductions on left frontal tests with hypnosis. Psychological Medicine, 23(1), 93-101.

Watanabe, E., Fukuda, S., Hara, H., Maeda, Y., Ohira, H., \& Shirakawa, T. (2006). Differences in relaxation by means of guided imagery in a healthy community sample. Alternative Therapies in Health and Medicine, 12(2), 60-66.

Weitzenhoffer, A. M., \& Hilgard, E. R. (1962). Stanford Profile Scales of Hypnotic Susceptibility, Form C. Palo Alto: Consulting Psychologists Press. 


\title{
NEW FINDINGS IN ACTIVE-ALERT HYPNOSIS: PHENOMENOLOGICAL, PHYISIOLOGICAL AND NEDOCRINOLOGICAL ANALYSES
}

\author{
KASOS, ENIKÔ - KASOS, KRISZTIÁN - JÓZSA, EMESE - KÖLTŐ, ANDRÁS - \\ BÁNYAI, ÉVA - VARGA, KATALIN
}

\begin{abstract}
Active-alert hypnosis represents an important milestone in the study of hypnosis, refuting the so far predominant theory that hypnosis is a sleep-like state. Still there are relatively few studies focusing on the active forms of hypnosis, especially with the systematic examination of active-alert hypnosis. The following article summarises two already published studies, investigating the endocrinological, electrodermal and phenomenological aspects of active-alert hypnosis, all the while emphasizing the interactional framework. In the first study - through analysing changes in electrodermal activity - we demonstrated that while in low hypnotizable subjects, left hemispheric dominance (characteristic of everyday alert consciousness) is retained until the end of active-alert hypnotic induction, in high hypnotizable the hemispheric dominance shows a shift to the right hemisphere. This pattern is associated with subjective alterations in the consciousness. In the second study it was found that active-alert hypnosis can influence cortisol and oxytocin levels in both the subject and the hypnotist, and the intensity of the endocrine changes are associated with the subject's hypnotizability and phenomenology of altered states of consciousness. These findings can be integrated to the interactional approach to hypnosis, and they support the beneficial therapeutic effects of active-alert hypnosis.
\end{abstract}

Keywords: active-alert hypnosis, altered state of consciousness, psycho-endocrinology, electrodermal activity, oxytocin, cortisol

A cikk a Creative Commons Attribution 4.0 International License (https:// creativecommons.org/licenses/by/4.0) feltételei szerint publikált Open Access közlemény, melynek szellemében a cikk bármilyen médiumban szabadon felhasználható, megosztható és újraközölhetô, feltéve, hogy az eredeti szerzô és a közlés helye, illetve a CC License linkje és az esetlegesen végrehajtott módosítások feltüntetésre kerülnek. (SID_1) 